\title{
Demagogy and Social Pathology: Wendy Brown and Robert Pippin on the Pathologies of Neoliberal Subjectivity
}

\section{Demagogia y patología social: a propósito de las reflexiones de Wendy Brown y Robert Pippin sobre las patologías de la subjetividad neoliberal}

\author{
Tom Bunyard ${ }^{1}$ \\ University of Brighton (Reino Unido)
}

Recibido: 05-02-19

Aprobado: 11-05-19

\begin{abstract}
This essay argues that modern demagogy can be understood as a symptom of a kind of social pathology, combining Wendy Brown's account of neoliberal subjectivity with elements of Robert Pippin's interpretation of Hegel to do so. I begin by focussing on Brown's contention that neoliberal society has bred forms of individual subjectivity that are inherently attuned to right-wing rhetoric. Drawing on Pippin's reading of Hegel, the essay casts these modes of individual subjectivity as aspects of a flawed mode of collective subjectivity; the contemporary rise of demagogic politics is thereby presented as a symptom of a pathological failure of collective self-determinacy, caused by inadequacies within the normative structures that articulate social activity.
\end{abstract}

Key-words: Brown, demagogy, Foucault, Hegel, neoliberalism, Pippin, social pathology, subjectivity.

\footnotetext{
${ }^{1}$ (T.Bunyard@brighton.ac.uk). Teaches philosophy and cultural and critical theory at the University of Brighton. Much of his previous work has focussed on the Hegelian and Marxian dimensions of Guy Debord's theoretical writings (as set out in his recent Debord, Time and Spectacle: Hegelian Marxism and Situationist Theory (Haymarket, 2019)). His current research is an attempt to develop elements of this work on Debord by combining Robert Pippin's reading of Hegel with contemporary Marxian value theory.
} 


\section{Resumen}

Este ensayo argumenta que la demagogia moderna puede ser entendida como un síntoma de una especie de patología social, combinando el relato de Wendy Brown sobre la subjetividad neoliberal con elementos de la interpretación de Robert Pippin sobre Hegel. Comienzo centrándome en la afirmación de Brown de que la sociedad neoliberal ha creado formas de subjetividad individual que están en sintonía con la retórica de la derecha. Basándose en la lectura de Pippin de Hegel, el ensayo presenta estos modos de subjetividad individual como aspectos de un modo defectuoso de subjetividad colectiva. El surgimiento contemporáneo de la política demagógica se presenta así como un síntoma de un fracaso patológico de la autodeterminación colectiva, causado por las insuficiencias dentro de las estructuras normativas que articulan la actividad social.

Palabras-clave: Brown, demagogia, Foucault, Hegel, neoliberalismo, Pippin, patología social, subjetividad.

\section{Introduction}

In a recent article in Critical Times, entitled 'Neoliberalism's Frankenstein', Wendy Brown argues that neoliberal social relations have created a monster. Building on Foucault's indications that neoliberalism is not just an economic project, but rather "a governing rationality generating distinctive kinds of subjects", ${ }^{2}$ she contends that neoliberalism's contemporary formations have produced a particularly dangerous kind of subject: a mode of subjectivity that has an inherent tendency towards expressing its frustrations in nationalist and authoritarian forms, and which is also highly susceptible to manipulation.

Brown does not define her use of the word "subjectivity", but it seems clear from both how she uses it and from the Foucaultian inspiration of that usage, that it is intended to denote the socially informed dispositions of individual agents. Her claim is that the advance of neoliberal social projects over the past several decades has affected the attitudes, aspirations, and comportment of individuals within society. ${ }^{3}$ The manner in which this has taken place is held to stem from the conception of freedom that informs neoliberalism's general rationale (she refers to the latter as "neoliberal reason" "). This is a notion of freedom in which liberty is identified with the independence of the private individual, and in which perspectives and projects that focus on what she

\footnotetext{
${ }^{2}$ Brown (2018), 61 .

See also Brown 2015.

${ }^{4}$ Brown (2018), 67.
} 
refers to as the "social" (e.g. social planning, social provision, social justice, etc.) are viewed with scepticism, and even antipathy. The result, she claims, is the dispersal, throughout the populace, of subjective dispositions that are inclined towards an emphasis on the private and the individual, and wary of the potentially domineering effects of the state and social provision; dispositions that are thus acclimatised to the break-up and privatisation of social structures, and wary of resistance to marketisation. Furthermore, this has also bred a more general inclination towards the affirmation of particularity vis $a$ vis universal rules and structures: an inclination towards asserting and defending particular identities, traditions, beliefs and opinions, and towards rejecting formations such as the state, secularity, cosmopolitanism, and - at the extreme - the impersonal rulings of science and reason. ${ }^{5}$ Brown's central contention, then, is that the neoliberal restructuring of society has provided fertile ground for the recent popular turn towards the political right.

Although demagogy is not Brown's primary focus in this text, her argument bears directly on questions concerning the contemporary prominence and success of demagogic politics. Because the subjectivity that she describes is primed to respond to right-wing and nationalist rhetoric, its frustrations can be easily channelled through such rhetoric; and when those frustrations are fed by socio-economic problems and privations, as is the case today, demagogy of this kind can flourish. Furthermore, Brown's approach also serves to highlight an important aspect of modern demagogy: it implies that the latter cannot be fully explained by looking solely at the actions and claims of specific demagogues, or indeed at the socio-economic conditions and media that have driven audiences towards them. Instead, it indicates that the roots of modern demagogy need be traced to a more fundamental basis, located in the ways in which modern social relations shape individual subjectivities. This entails that her essay carries a further implication. Because her account highlights a general propensity towards such politics, it is not only relevant to the rise of our most prominent modern demagogues: it can also offer a useful perspective on related cultural and political phenomena (e.g. the growth of right-wing media punditry; the online spread of conspiracy, outrage and misinformation; the rise of the so-called 'alt-right'; the current host of provocateurs, gurus and self-

\footnotetext{
${ }^{5}$ Brown's remarks can be supplemented here by noting that this emphasis on individual opinion, and indeed the skepticism that it engenders towards more substantial truth-claims, accords with some of the ambitions of the original neoliberal theorists. According to Hayek, for example, "the case for individual freedom rests chiefly on the recognition of the inevitable ignorance of us all" (quoted in Mirowski (2013), 78), and on the view that the market can function as "an information processor more powerful than any human brain" (Mirowski (2013), 54). Hayek, in other words, was certain (contradictorily) that the market is the only source of genuine certainty regarding social policy and provision (see Brecher 2019 for commentary on this point). Such a view entails that any presumption to be able to ascertain what really is good for ourselves and for society can only seem hubristic, and indeed be tantamount to the arbitrary imposition of one subjective viewpoint upon all others.
} 
proclaimed 'outsiders' who purport to challenge the values of a liberal elite; etc.). ${ }^{6}$ If the term 'demagogy' can be understood to encompass such varied phenomena - and I would argue that it should indeed be so understood ${ }^{7}-$ then Brown's approach offers a means of theorising their common basis. This then renders it possible to view modern demagogy as a symptom of a kind of social pathology, i.e. as a symptom of a flawed set of social relations. My aim in this essay is to try to develop that implication, although I shall do so by adopting a rather different theoretical framework from Brown's own.

I should emphasise that 'social pathology' is not a phrase that Brown uses (in fact, her caution towards normative evaluations of politics and power would entail a degree of distance from the way in which I intend to employ the term here). My use of the term is informed by the work of the prominent Hegel commentator Robert Pippin. ${ }^{8}$ For many years, Pippin has advanced an ingenious reinterpretation of Hegel's philosophy that cuts away the latter's grander metaphysical aspects, and which re-casts many of the elements of Hegel's work that seem hard to sustain today. ${ }^{9}$ I shall outline this interpretation below, but suffice it to say here that it places particular emphasis on Hegel's presentation of reason as a collective and social enterprise. 'Spirit', for Pippin, is not some kind of animistic cosmic force, as in many traditional readings of Hegel: instead, it is simply reason, albeit reason understood as a collective, social activity. Importantly for our concerns, Pippin also stresses that the operation of such collective rationality is prone to periodic breakdowns and crises. In his reading, these breakdowns are caused by failings in the basic coherence and unity that a community requires in order to shape and determine its affairs freely, self-consciously, and collectively.

These ideas inform a recent article that Pippin wrote in the wake of the Trump election: 'Hegel on Social Pathology: The Actuality of Unreason'. The essay suggests that Hegel's indications concerning such failings and breakdowns could be used to illuminate the "collective irrationality" 10 of our own contemporary circumstances. With that suggestion in mind, I shall try to place Pippin's notion of social pathology in relation to Brown's diagnosis. By combining the salient elements of their analyses, I hope to arrive at a perspective

${ }^{6}$ Brown clearly has such a broad spectrum of phenomena in mind: two of her essay's three epigraphs concern Marine Le Pen and UKIP, and the third refers to Milo Yiannopoulos.

${ }^{7}$ All such phenomena involve the pursuit of political agendas by pandering to the immediacy of popular emotion, rather than to rational deliberation. All exploit popular desires, prejudices and fears, and set the latter's energies against the complacencies and ineffectuality of a supposed status quo.

${ }^{8}$ My approach will also differ from that of Axel Honneth, who has become closely associated with an overtly normative conception of social pathology. In place of Honneth's focus on recognition, I shall draw on Pippin's interest in the production, use and contestation of the norms that articulate social activity.

${ }^{9}$ This interpretation was set out most fully and originally in his Hegel's Idealism: The Satisfactions of Self-Consciousness (Pippin 1989), and has been developed in Pippin's many subsequent works.

10 Pippin (2017), 350. 
on the social pathology proper to modern neoliberal demagogy. To that end, I shall adopt the following approach: where Brown uses Foucault to talk about pathological forms of individual subjectivity, I shall draw on elements of Hegel's philosophy, and on Pippin's interpretation thereof, to propose that deeper problems might lie in the form of collective subjectivity that constitutes our current social formation. I shall then propose that much modern demagogy (broadly construed, as above) can be understood as a symptom of that deeper pathology, and thus as an indication of a failure of coherent collective selfdeterminacy.

Needless to say, that statement of intent demands an explanation of what it might mean to talk about a 'self-determinate' 'collective subject', and a fuller defence of why it might be relevant to do so. I shall try to provide such explanations below. They will prove easier, however, if I first describe Brown's claims in a little more detail.

\section{The Neoliberal Frankenstein}

As we have seen, Brown's argument is centred around the conception of freedom that she sees as constitutive of "neoliberal rationality". ${ }^{11}$ Through a discussion of the ideas of Friedrich Hayek - one of the chief architects of modern neoliberalism - she contends that this is a view in which freedom is essentially understood in terms of the absence of restrictions, and in which the individual agent is absolutely primary. The best way to avoid such restrictions, according to Hayek, and to thereby maximise individual freedom, is to organise society on the basis of market principles. This is because doing so would entail prioritising individual choice. The social programme that follows from these views is one in which the private sphere should be expanded and left as unregulated as possible, and in which the social (the shared, collectively managed, and state-organised elements of society) should be progressively restricted and privatised.

According to Brown, the resultant neoliberal drive towards the expansion of the private, and towards the concomitant restriction of the social, has been pursued to such an extreme degree that the private has now virtually swallowed the social. This has given rise to what she describes as a "new ethos of the nation", ${ }^{12}$ insofar as a "public, pluralistic, secular democratic national imaginary" has been steadily replaced with what she calls a "private, homogenous, familial one." 13 Her argument here is that, because the private

\footnotetext{
11 Brown (2018), 61 .

12 Brown (2018), 65-6.

13 Brown (2018), 65-6.
}

Araucaria. Revista Iberoamericana de Filosofia, Politica, Humanidades y Relaciones Internacionales, año $21, \mathrm{n}^{\circ} 42$. Segundo semestre de 2019. Pp. 505-527. ISSN 1575-6823 e-ISSN 2340-2199 doi: 10.12795/araucaria.2019.i42.22 
and the familial have practically encompassed the social, the nation as a whole has become reconceived in the popular "imaginary" as a peculiar hybrid of business and home. Just as a domestic home is a private sphere characterised by distinct traditions, customs, characteristics, and attitudes - a space that ought to be kept distinct from external, universalising impositions - so too is the national 'home' conceived, in this "imaginary", as a space characterised by distinct traditions, cultural identities and beliefs. Such a space is thus in need of protection from abstract, transnational entities and values, and from threatening invaders and freeloaders. Moreover, just as a business requires strong, decisive management, able to make 'good deals', so too is the nation in need of a leadership able to operate as just such an executive. This dual notion of the private - both business and home at one and the same time - lends itself to support for authoritarian, pro-capitalist nationalism. ${ }^{14}$

This inclination is compounded by a tendency towards irrationality on the part of individual subjects (although I should add that 'irrationality' is my term, not hers). Brown argues that the identification of freedom with the private entails the prioritisation and affirmation of individual, independent belief. The attitudes fostered by neoliberalism thus invite the elevation of personal opinions and faiths over the more universal and impersonal rules of reason and science. When this is coupled to the tendency towards authoritarian nationalism outlined above, it renders those whose 'subjectivities' have been shaped in this manner prone to manipulation and influence by "plutocrats, Right-wing politicians, and tabloid media moguls". ${ }^{15}$

Yet as Brown acknowledges, all this is not enough, on its own, to explain the appetite for right-wing demagogy that characterises our contemporary context. As she puts it: "Neoliberal reason by itself ... does not generate nationalist movements hell-bent on whitening nations, walling out immigrants and refugees, or vilifying feminists, queers, liberals, leftists, intellectuals, and even mainstream journalists." 16 This requires a change in material conditions, capable of generating frustrations that can be readily articulated in this manner. This, according to Brown, has been provided by international and domestic economic shifts that have worsened the status and conditions of the "white working and middle class inhabitants" of the "Euro-Atlantic". ${ }^{17}$ Owing to a combination of post- financial crisis austerity, growing inequality, and changes in the global flows of capital, trade and manufacture, these individuals are now facing diminishing socio-economic status, growing insecurity, and declining access to "decent incomes, housing, schools, pensions, and futures". ${ }^{18}$ When

\footnotetext{
${ }^{14}$ See Nicola Clewer's essay in this volume.

15 Brown (2018), 75.

${ }^{16}$ Brown (2018), 68

17 Brown (2018), 61 .

18 Brown (2018), 61.
} 
channelled through the 'ethos' and subjectivity outlined above, Brown argues, the resulting disaffections can easily slip into resentment towards job-stealing foreigners (understood as dangers from 'outside'), threats to patriarchal, moral and religious traditions (understood as impositions upon 'private' custom), and towards a detached, condescending, 'politically correct' liberal elite (associated with the universalising dictates of the social). "Et voila", she writes: "twentyfirst century authoritarianism in freedom's name!"19

This then brings us to the 'Frankenstein' metaphor invoked by the title of Brown's essay. Where Mary Shelley's hapless doctor unwittingly fashioned a monster through the pursuit of science, the concerns with freedom that motivated the original neoliberal theorists have, for Brown, produced a similarly destructive outcast; and just as Victor Frankenstein sought to create a figure of reason and beauty, but instead produced a wounded monster, so too, for Brown, have the neoliberals created an entity that differs sharply from their intentions. ${ }^{20}$ "Far from the calculating, entrepreneurial, moral and disciplined being imagined by Hayek and his intellectual kin," she writes, "this one is angry, immoral and impetuous, spurred by unavowed humiliation and thirst for revenge", ${ }^{21}$

I shall return to the issues raised by this metaphor below, because it is surely one of the most questionable aspects of her entire essay (casting great swathes of the aggrieved working class as a 'monster' is redolent, to say the very least, of the liberal elitism that this same subjectivity has turned against). But to sum up at this point: Brown's analysis locates the roots of far-right populism, and thereby those of the demagogic politics that the latter feeds, within a form of subjectivity that stems from the social relations that compose modern society. Now, if this account can be taken to identify a kind of social pathology, as I proposed at the outset of this essay, then how might we characterise that sickness?

\section{The universal and the particular}

Brown's diagnosis amounts to an identification of a pathological mode of prioritising the particular over the universal. If we follow the steps of her argument, the progress of the disease would seem to work as follows.

\footnotetext{
19 Brown (2018), 68.

20 As Mirowski points out, "the starting point for neoliberalism is the admission ... that the conditions for its existence must be constructed, and will not come about "naturally" in the absence of concerted political effort and organisation' (Mirowski (2013), 53n). The neoliberal dissolution of 'the social', to use Brown's term, was thus a deliberate, and highly successful, project. Her Frankenstein metaphor is certainly problematic, but it is also apt, insofar as the neoliberal restructuring of society necessarily entailed the re-shaping of beliefs, aspirations, and modes of comportment.

21 Brown (2018), 78.
} 
(1) Firstly, neoliberal policies undermine the social in favour of the private, producing subjects inclined towards affirming individual freedom, and towards rejecting universalising impositions. (2) This inclination is then fed by forms of demagogy, which help to channel socio-economic frustrations into demands for the defence of individual freedom. The latter is, in consequence, seen to be threatened by attacks upon the status of particular identities, beliefs, traditions, and forms of individual agency. (3) This then prompts further, defiantly aggressive, affirmations of particularity: hence the angry contemporary endorsements of nationalism in response to the abstract universality of 'globalism'; of ethnicity and tradition against cosmopolitanism; of customary gender roles against the supposed dictates of 'political correctness', feminism and equality; and of individual faith vis a vis science and reason (this list could, of course, continue).

If this analysis of our contemporary situation is broadly correct - and in my view, it seems perceptive, at least as regards the political culture of the modern West - then what would be the relevance of adopting the more Hegelian stance to which I referred earlier? In what way might it be able to supplement Brown's analysis?

The point is that Hegel's philosophy is fundamentally concerned with the relation between universality and particularity. The details of that concern form the heart of his complex metaphysics, which cannot be addressed here, but the general theme of his ambitions in this regard can be introduced by simply noting that his work is not the imperialistic, domineering logic of legend. One of the primary charges that is often levelled against Hegel's philosophy is that it suppresses all particular differences and identities under the totalising rule of a universal identity. The infamous Hegelian 'Absolute', on this view, becomes a kind of ultimate, catch-all transcendental category, which Hegel and his followers have rudely and forcibly hammered down onto the subtle distinctions and variations of the historical world (Hegel's metaphysics, on this view, offers a perfect example of the kind of imposition that neoliberal thought allegedly seeks to avoid). ${ }^{22}$ Yet Hegel was explicitly opposed to any such enterprise, and instead set out to conceive a kind of immanent, organic and harmonious relation between the universal and the particular, and thus between identity and difference. To quote the Logic: his aim was to set out a kind of thought in which "the universal ... takes its other within its embrace, but without doing violence to it", insofar as it is, "in its other, in peaceful communion with itself". ${ }^{23}$ This concern is also evident in Hegel's social and political philosophy, where he argues for a mode of organisation in which the universal structure of the social whole is not imposed upon, but rather arises from, the particular individuals

\footnotetext{
${ }^{22}$ See Stewart (1996) for useful responses to this view.
}

${ }^{23}$ Hegel (1969), 603. 
from whose activity it emerges. ${ }^{24}$ Such a perspective entails finding fault in social formations in which the universality of the state functions as an alien imposition on the individuals concerned; in formations that are marked by clashing, fragmented, factional elements; or in social structures that amount to aggregations of atomised individuals.

There is, of course, a great deal more to be said here, but I hope that these remarks serve to at least indicate the relevance of Hegel's ideas to the pathological prioritisation of the particular, and to the denigration of the universal, that I highlighted in Brown's account of neoliberal capitalism. As I shall now try to show, this then means that that pathology can be construed, following Pippin, as a set of failures in a mode of collective subjectivity. In order to develop that claim, however, I must first set out some general remarks about Hegel's understanding of subjectivity.

\section{Collective subjectivity}

The issues involved here are very complex and technical, so I hope that I can be forgiven for painting them in rather broad brushstrokes. But to put it very simply and abruptly: a 'subject', for Hegel, is an entity that generates differentiation within itself; maintains and develops its identity throughout those differentiations; and possesses a degree of self-awareness. Individual human agents are 'subjects' in this Hegelian sense: one might think here of the emergence of distinct mental states within the apperceptive unity of a single human mind, or of the different actions and experiences that make up the moments of a single human life. These particular moments emerge within, and both give rise to and form part of, a universal whole. Hegel also uses this idea to think about the unity and persistence of a distinct community through time. As a collective 'subject', that community has an identity that arises from, and which is sustained throughout, the differences that emerge within it, i.e. from the different lives, actions, and interactions that compose the 'life' of that community. This is central to Pippin's understanding of Spirit (or, to be precise: to Pippin's understanding of what Hegel calls "objective Spirit"). ${ }^{25}$

In a traditional reading of Hegel, Spirit is typically understood as the vehicle through which a grand, quasi-pantheistic reason slowly ascends towards full realisation and self-awareness. Pippin's reading is shorn of any such cosmic monism. It presents reason solely as the shared system of concepts,

\footnotetext{
${ }^{24}$ Hegel's view that such a state of affairs could be achieved in a highly patriarchal constitutional monarchy (see Hegel 2005) is a classic example of the obvious tension between the potentially radical content of his philosophy and its conservative pronouncements. See Clark (2013), 65-8 for an argument that holds that this same tension can be identified within Pippin's work.

${ }^{25}$ Pippin (2017), 335.
} 
norms and practices that articulates the operation of a collective subject. So, to put it rather reductively: Spirit, for Pippin, is a collective subject; ${ }^{26}$ reason is the shared, collective means by which the actors who compose that subject understand themselves and their world. Reason, in other words, affords the shared commitments, practices, patterns of behaviour and history, etc., that mediate the actions and interactions of the collective's members, and which thereby give rise to a particular mode of social life.

This entails that such a collective subject can be understood (to quote one of Hegel's most famous descriptions of Spirit) as both an "I that is we", and a "we that is I". ${ }^{27}$ That formulation does not denote totalitarian uniformity. Instead, and to borrow Pippin's phrasing, it simply means that 'while any individual I comes to be the I it is and maintains its sense of itself within a common mindedness, it is also the case that this common mindedness is only possible by the attitudes and commitments of distinct, individual "I's", The commonality afforded by the social operation of reason thus amounts to a kind of shared self-awareness, articulated by the "shared beliefs, attitudes [and] dispositions that the sharing members know are shared". ${ }^{28}$ So Hegel is not describing a mode of subordinating particular individualities under the rubric of a single, monolithic, group identity: instead, this commonality is a medium, composed of shared values, norms, attitudes and practices, within and through which such individualities can emerge, persist, and interact as elements of a whole. There is a great deal more to be said here concerning the nature of these shared norms and practices, and indeed concerning Pippin's claim that they change, develop and collapse over time. I shall return to some of these details later. Here, however, I want just to underscore the following two points. Firstly, collective subjectivity, understood in these terms, is a structure that enables collective self-determination; and secondly, this structure, and the selfdeterminacy that it affords, stems from the interrelation of the universal (shared norms and practices) and the particular (individual agents who interact through those shared norms). A pathological failure of such interrelation would thus weaken, undermine, and perhaps even thwart such collective self-determinacy. This brings us back to Brown's claims.

I argued above that the problems that Brown identifies follow from a denigration of the social vis a vis the individual that could be understood as a flawed relation between the universal and the particular. If we look at that diagnosis through the lens of the Hegelian ideas that I have outlined here, Brown's account of pathological forms of individual subjectivity could be construed as pointing towards the deeper problem of collective subjectivity.

\footnotetext{
${ }^{26}$ Pippin (2017), 335; for a slightly contrasting view see Inwood (2003), 280-3.

27 Hegel (1977), 110.

28 Pippin (2017), 334.
}

Araucaria. Revista Iberoamericana de Filosofía, Política, Humanidades y Relaciones Internacionales, año $21, \mathrm{n}^{\circ} 42$. Segundo semestre de 2019. Pp. 505-527. ISSN 1575-6823 e-ISSN 2340-2199 doi: 10.12795/araucaria.2019.i42.22 
Seen in these terms, the story would run as follows: the neoliberal privatisation of the social lends itself to the latter's dissolution; this produces the toxic individual subjectivities with which Brown is concerned, but it also breeds the breakdown of the kinds of social mediation and coherence required for collective self-determinacy (one could propose a reciprocal relation here, wherein the privatisation of the social generates subjective dispositions that then exacerbate social fragmentation). Remaining within the ambit of Brown's claims, we could then contend that the particularistic confusion of nation, home and business described earlier, and the concomitant prioritisation of particular beliefs vis a vis facts and established discourses, give rise to the factional fragmentation proper to our purportedly 'post-truth' circumstances. Such confusion would amount to a pathological failure or weakening of collective self-determinacy.

These ideas could also help us to go somewhat further than Brown in thinking about the roots of modern demagogic politics. For according to the perspective outlined here, failures in the mediating structures and norms that articulate social activity foster separation, oppositional group identities, and a general loss of orientation and direction. They should be expected, therefore, to give rise to, and to be furthered by, forms of demagogy that purport to express the conflicting demands and identifications that result from such a loss of unity.

\section{The monstrosity of an absent subject}

Importantly, this approach offers a means of remedying an important shortcoming in Brown's account. Brown's Frankenstein metaphor places her essay very close to a problem that runs throughout a good deal of contemporary commentary on populist politics: namely, a kind of horrified reification of the working class, in which the latter are confusedly and reductively identified with factional characteristics (e.g. white, nationalist, chauvinist, etc.) that stem from the demagogic manipulation of social grievances. ${ }^{29}$ The manner in which this plays out in Brown's essay seems to derive from the way in which she employs Foucault's ideas.

As we have seen, Brown's Foucaultian version of subjectivity concerns the dispositions and comportment of individual agents. By describing a broad demographic under this rubric, she comes extremely close to characterising that entire demographic. And this amounts to a reification of the latter, because this characterisation involves treating the political actions of such individuals as indicative expressions of their nature (or, rather, of their 'subjectivity', in the Foucaultian sense of that term). Consequently, and inadvertently, Brown

${ }^{29}$ These claims are informed by Alberto Toscano's 'Notes on Late Fascism' (Toscano 2017). 
ends up presenting an account of a collective agent of some kind: a unitary whole that possesses a distinct and relatively uniform character and mode of comportment. The problem, of course, is that this obscures the sense in which the forms of popular politics with which she is concerned are not the expressions of a coherent class subject, possessed of some kind of distinct collective orientation. Instead, they are symptomatic of the absence, or at least of the denigration, of any such collective agency.

Surely one of the primary aspects of the contemporary situation is that it is not marked by unified individuals, operating as a whole, but rather by masses of individuals, who, in the absence of such orientation, feel all the more acutely the attraction of the answers, sureties and direction proffered by demagogic figures and cultural phenomena. This desire for certainty and direction pertains, I think, to the enormous contemporary success of demagogic gurus (such as Jordan Peterson, ${ }^{30}$ whose best-selling conservative self-help book is even subtitled "An Antidote to Chaos"31) and conspiracy theorists (Alex Jones, for example), ${ }^{32}$ to the sense of righteous indignation afforded by aligning oneself with free-speech 'martyrs' (e.g. Tommy Robinson ${ }^{33}$ and others); or indeed to the darkly euphoric sense of belonging that comes from horrifying the liberal sensibilities of a stagnant status quo (Milo Yiannopoulos, ${ }^{34}$ the online manifestations of the 'alt-right', ${ }^{35}$ and, in a much weaker sense, the Trump election and the Brexit referendum). My suggestion here is simply that the appeal of the sense of identity, meaning and direction offered by all such demagogic narratives stems from the fragmentation and confusion proper to a pathological form of collective subjectivity. Or, to put that much more bluntly: people are drawn to demagogic images of meaning, direction and belonging, due to the impoverishment of more concrete forms of collective orientation (i.e. due to a pathology of collective subjectivity, in the sense described above).

${ }^{30}$ Peterson is a Canadian psychologist and social commentator who has risen to fame over the past several years due to the tremendous success of his 12 Rules for Life: An Antidote to Chaos (Peterson 2018), and the prominence of his videos on Youtube. Peterson is able to combine accessible, and at times insightful, critical observations about modern society with comfortingly familiar ideological tropes concerning the merits of tradition and patriarchal values. His work is thus particularly suited towards articulating and framing the frustrations of young, white, men, whose position in society has been eroded by post-financial crisis neoliberalism.

31 Peterson (2018).

32 Jones is a prominent American conspiracy theorist whose website and radio show advance a peculiarly furious and paranoid version of libertarianism.

33 Robinson, whose real name is Stephen Yaxley-Lennon, is a British far-right activist. He was a member of the British National Party (a far-right political party); he co-founded the English Defence League (an anti-Islamic organisation); and he is currently an advisor to the U.K. Independence Party. Much of his current prominence stems from his success in presenting himself as a proponent of free speech who has been silenced by a politically correct elite.

34 Yiannopoulos is an internet celebrity who has created his fame through advancing deliberately controversial, provocative, and offensive views. He was an editor of Breitbart News, is associated with the alt-right, and, like Robinson, has been able to position himself as a free-speech 'martyr'.

35 See Nagle (2017) for useful commentary on this phenomenon. 
This is not to deny that Brown's account accommodates some of these issues, but she does so less explicitly, and in rather different terms. As we shall see shortly, her notion of subjectivity is able to address the sense in which modern unrest is not just motivated by forms of material privation, but also by the existential impoverishment described here. By the latter term, I mean to denote the sense of futility that follows, for large sections of the populace, from a lifetime of debt, pointless jobs, and inaccessible social goods: a malaise that is only exacerbated, in however diffuse a manner, by the ecological and economic problems that loom on the collective horizon. The resentments proper to such existential impoverishment - a poverty that really arises, according to the view that I have proposed here, from a loss of collective self-determinacy - can only exacerbate the appeal of demagogic answers. Brown touches on such issues, but her lack of a notion of collective subjectivity limits the purchase of her account. This limitation could be addressed, I think, by drawing on aspects of Pippin's interpretation of Hegel. To that end, we now need to look at some of the details of his claims. ${ }^{36}$

\section{Pippin's Hegel}

As we saw earlier, Pippin's interpretation avoids the quasi-pantheistic dimensions of Hegel's metaphysics. It does so by re-casting the latter in broadly Kantian terms. Hegel is traditionally understood to have claimed that all being (i.e. the cosmos itself) is conceptually structured. In contrast, Pippin's Hegel advances a more modest contention: for this Hegel, it is not being per se that is conceptually structured, but rather all intelligible being (i.e. all that being could ever intelligibly be for us). ${ }^{37}$ This is because, for Pippin's Hegel, our understanding of the world is generated by the concepts that allow us to conceive an objective reality. As in Kant, our use of these concepts is governed by normative rules. Such normative concept-use articulates the operation of the collective subjectivity that I described above, and it affords the shared modes of recognition, activity, and intelligible agency that that operation requires.

Crucially, those shared patterns of norm-based activity and sense-making are also held to be subject to change. Pippin's claim here is that, through social activity and interaction, we generate, employ, contest, and reformulate the shared norms through which we render our environment and actions mutually intelligible (e.g. the acknowledged meaning of a particular object, the significance and appropriateness of a kind of activity, etc.). This entails

\footnotetext{
${ }^{36}$ I am indebted to Robb Dunphy for his help with some of the more obscure elements of Pippin's reading of Hegel.

37 Pippin (2005), 49.
}

Araucaria. Revista Iberoamericana de Filosofia, Política, Humanidades y Relaciones Internacionales, año $21, \mathrm{n}^{\circ} 42$. Segundo semestre de 2019. Pp. 505-527. ISSN 1575-6823 e-ISSN 2340-2199 doi: 10.12795/araucaria.2019.i42.22 
different modes of cultural practice, and thus different instantiations of 'Spirit', but as in Hegel himself, it does not involve complete relativism.

In Pippin's reading, the structure of collective subjectivity - a structure that depends upon mutual recognition and the mutual comprehension of particular subjects and objects via universal norms - is not simply given to us. The rules and concepts that articulate the way we think and act are not derived empirically, or drawn from any external, transcendental source..$^{38}$ Instead, they are held to be have been generated from, and revised through, the course of social activity. This means that, for Pippin's Hegel, collective subjectivity is an achievement, ${ }^{39}$ not a given, and something that can be done well, or badly. Success in this regard is tantamount to the degree to which a structure of collective subjectivity affords the free agency of the individuals who compose it.

Unlike Hayek - and indeed unlike much of the liberal tradition ${ }^{40}-$ Hegel does not conceive freedom as the absence of impositions upon individual liberty. Instead, freedom, for Hegel, is a necessarily collective condition ("I am only truly free", he writes, "when the other is also free"). ${ }^{41}$ In Pippin's interpretation, this follows from the relation between a) the social operation of reason, and b) individual agency. The key idea here is that my actions are only really mine when I can justify and explain them. This requires mutual recognition, common norms of practical rationality, and shared conceptual structures. Without those requirements, my actions cannot be recognised, understood, and credited as my own by others. As Pippin puts it: "for the action to count as mine, it must make a certain kind of sense to the agent, and that means it must fit in intelligibly with a whole complex of practices and institutions within which doing this now could have a coherent meaning". ${ }^{42}$ This then means that the freedom of one individual (qua a rational agent able to offer and identify reasons for actions) is dependent upon the freedom of others (i.e. upon the shared, social nature of such normative reasons, and upon the availability and intelligibility of those reasons to other such agents). Neither mutual recognition nor these shared complexes of norms are automatically given to us. Instead, they arise from the agreements, conflicts, dilemmas, and disputes over meaning that surround our actions. Consequently, freedom, as I indicated earlier, is an achievement on this view, and something that a society can attain with varying degrees of success.

This then brings us to the following, key point. For Pippin, "one of the most interesting aspects of such a social condition" - i.e. the condition of shared norm-based interaction outlined here, and thus that of the "shared

\footnotetext{
38 “...[T] of possible claims to know could go on, no 'bar of reason', above the fray [of Spiritual life], to which candidate accounts could be brought for hearing" (Pippin (2007), 60).

39 Pippin (2008), 9.

${ }^{40}$ Houlgate (2005), 183-4.

${ }^{41}$ Quoted in Chitty (2013), 687/

42 Pippin (2008), 5, emphasis in the original.
} 
meaningfulness, or intelligibility", that affords rational activity - is that "it can fail, go dead [or] lose its grip". ${ }^{43}$ 'Failure', in this sense, means an inability to afford coherent rational self-determination. The complexes of norms that articulate the operation of a community can fracture, and elements thereof can collapse. If that occurs, the common-mindedness required for collective freedom is undermined.

Such a situation could arise because the norms involved might be in contradiction (to use one of Pippin's examples: a commitment to equality before the law may be incompatible with a commitment to a justice system that rewards privilege). ${ }^{44}$ Some norms would then require of the agent "further commitments incompatible with others necessary within some form of life", ${ }^{45}$ thus weakening the cohesion of the whole. Or, one might find oneself "confronted", as Pippin puts it, "by possibilities of work ... or political choices that are not experienced as possible expressions of one's own commitments", 46 because the institutions and customs involved may have started to seem hollow to the actors involved. Reasons may well be available for my actions (e.g. the expectations of others, the pursuit of money, etc.), but they may ring false when called upon to serve as my reasons. If that occurs, Pippin writes, we would "not want to say that the action is truly 'mine', such that I can fully or truly stand behind it, own up to it, claim ownership of it". ${ }^{47}$ In a more extreme case, the activities in question may even be "part of a [social] practice that has ... gone dead in a certain way". ${ }^{48}$ If my actions involve jarring commitments; if they do not make sense to me; or if they simply do not make sense to others, as elements of a network of recognised practices and institutions; then they cannot be instances of the collective rational agency of a social whole.

As I hope is already apparent, the ideas sketched here can be readily applied to contemporary phenomena. They can be used to explain, for example, the current profusion of wat David Graeber has aptly termed "bullshit jobs"; 49 they relate to the widespread loss of faith in modern politics; to the confusion and fragmentation fostered by 'post-truth' phenomena; to the factional nature of populist discourse, and to the lack of coherence between the allegiances, ambitions and understandings of social actors that this involves; and indeed to more general and diffuse forms of scepticism towards the current social structure. Pippin's work can, therefore, provide a useful framework for addressing the failings that engender the loss of meaning, disorientation and malaise that render the apparent answers and certainties provided by demagogic rhetoric so appealing.

\footnotetext{
43 Pippin (2008), 6.

${ }^{44}$ Pippin (2017), 340.

45 Pippin (2008). 5.

${ }^{46}$ Pippin (2017), 342.

47 Pippin (2008), 5.

48 Pippin (2008), 5.

49 Graeber (2013).
}

Araucaria. Revista Iberoamericana de Filosofia, Politica, Humanidades y Relaciones Internacionales, año $21, \mathrm{n}^{\circ} 42$. Segundo semestre de 2019. Pp. 505-527. ISSN 1575-6823 e-ISSN 2340-2199 doi: 10.12795/araucaria.2019.i42.22 
Now, there are limits to this applicability. Pippin says relatively little about why breakdowns and failures occur, and seems content simply to address Hegel's own comments on the topic, and the philosophical questions of agency to which those comments give rise. He is, however, clearly of the view that these ideas may be relevant to contemporary society (hence his comments on Trump in his 'Social Pathology' essay, and his tendency to use examples drawn from modern life when illustrating his claims). If such a claim to relevance is to be persuasive, it must take account of the socio-economic structures at work within modern society. For if it does not do so, its account of normative breakdowns can become reducible to a commentary on the obstinacy and short-sightedness of the actors involved. In Pippin's 'Social Pathology' essay, the "collective irrationalities" 50 that led to Trump's presidency are effectively reduced to a failure, on the part of a large portion of the American public, to really think and talk things through. ${ }^{51}$ In short, this approach needs to be applied to the specificities of capitalist social structures. After all, what is capitalist value, if not a set of norm-governed social practices?

This points towards a line of further work, but one that I can do no more than suggest here. Pippin's Hegel offers a means of thinking about the ways in which abstractions have 'material' force, insofar as they are rooted in, and shape, social conduct. In consequence, this is a form of Hegelian idealism that is not necessarily incompatible with the central premises of Marxian materialism.${ }^{52}$ It may, therefore, be productive to read contemporary Marxian value-theory through something akin to Pippin's approach to social activity. This is because such theory tends to stress the sense in which economic value is not just a mental construct, but rather the very architecture of our lived social relations. The scope of this essay means that this possibility needs to be put to one side. Suffice it to say here, however, that Pippin's approach to social pathology requires some kind of socio-economic supplementation; and if Brown's account of neoliberal social relations can serve as a place-holder for such supplementation, we can turn now to the way in which Pippin's ideas might pertain to the nihilism that she associates with neoliberal subjectivity.

\footnotetext{
${ }^{50}$ Pippin (2017), 349.

${ }^{51}$ Pippin (2017), 350.

${ }^{52}$ Marx is frustratingly silent on the topic of the relation between concepts and reality (save, that is, for the second of the Theses on Feuerbach, which dismisses the issue as a "purely scholastic question" (Marx (1975), 423, emphasis in the original)). It seems safe to contend, however, that Marx's materialism, according to which "the ideal is nothing but the real world reflected in the mind of man" (Marx (1990), 102), needs to be tempered with the observation that "the real world" is shaped through human actions that are themselves articulated by thought (Marx, we should remember, was not a crude determinist). Consequently, I would argue that a theory that understands social activity to be shaped and governed by normative concept-use need not be entirely incompatible with this 'materialism'. This is because such norms (those that structure economic practices, for example) may not be under the direct or conscious control of their adherents, and may merely form part of the unquestioned (and yet conceptually mediated) architecture of the social world. That 'architecture' composes the material circumstances in which social activity is played out.
} 


\section{Modern nihilism and the loss of the 'Absolute'}

According to Brown, neoliberalism breeds forms of individual comportment that are characterised not only by self-regulation, competitiveness, and desires for individual self-advancement, but also by neuroses, confusion, nihilism and malleability. This is held to have fostered the peculiar mixture of irony, spite and fierce, identitarian belief that often characterises the new far-right's peculiarly hostile jouissance. ${ }^{53}$ When developing this part of her argument, she draws on Nietzsche's critique of nihilism. She is, I think, right to do so: his conceptions of nihilism, angrily reactive ressentiment, and of the pliability of modern values, do indeed have clear echoes in modern politics. Brown does not, however, do a great deal more than signal these echoes, so I shall try to supplement her observations with the following remarks.

Although Nietzsche is popularly understood as a proponent of modern nihilism, he was, as Brown acknowledges, one of its sharpest critics. Simply put, Nietzsche's view was that, whilst God may well be dead (or: whilst the notion of a firm foundation for truth-claims, values and moral sentiments may have collapsed), modern society remained characterised by the values that he had once propped up. With that support knocked out, those values became hollow and empty of meaning. ${ }^{54}$ This, for Nietzsche, gave rise to both a great problem and a great possibility. On the one hand, this emptiness generated the vacancy and apathy of Zarathustra's 'last men': individuals who have become as empty and baseless as the culture in which they reside. On the other hand, however, this same state of affairs had also led to a great insight: for once the scaffolding of traditional values was kicked away, it became all the more apparent, in Nietzsche's view, that these values are based on nothing more solid than a 'will to power'. But that insight does not entail nihilism. Instead, it amounts to a solution to the latter: for if this state of affairs is recognised, it becomes possible positively to embrace that foundational will, and to affirm the power of creation and liberation that it entails. This leads to the 'transvaluation of all values', the creative re-figuration of all extant moral and conceptual norms, that Nietzsche associated with the coming of the 'Superman' (a new, braver, and grander mode of existence).

Although Brown notes the salience of Nietzsche's worries about nihilism, she does not address the aspects of his thought that I have summarised here. Instead, she simply acknowledges his opposition to nihilism, and then moves on to connect his moral relativism to the fluidity of values within modern politics ("this phenomenon" of pliable values, she writes, "is ubiquitous", and is "quotidian" in both "the instrumentalization of values for commercial and

\footnotetext{
${ }^{53}$ See Nagle 2017.

${ }^{54}$ Nietzsche (2017), 11-13.
}

Araucaria. Revista Iberoamericana de Filosofia, Politica, Humanidades y Relaciones Internacionales, año $21, \mathrm{n}^{\circ} 42$. Segundo semestre de 2019. Pp. 505-527. ISSN 1575-6823 e-ISSN 2340-2199 doi: 10.12795/araucaria.2019.i42.22 
political gain", and in "the general lack of umbrage at this instrumentalization" 55 ). Having noted this loss of stable moral norms, she then links the joy that Nietzsche associated with the lack of moral restrictions to the grotesque, gleeful cruelty that often marks right-wing populism, particularly in its online manifestations. The latter connection is certainly persuasive ("to witness suffering does one good", says Nietzsche, as there is "no festivity without cruelty"56), but what is missing from Brown's account is the role played by the 'death of God' in his philosophy. This is important: for if one is to sustain the link between Nietzsche on the one hand, and modern nihilism on the other, then surely the primary issue is not simply the depthless flexibility of contemporary values, but rather the collapse of the anchor-points that once sustained them.

On one level, we could fill this gap in Brown's account by pointing to her own comments concerning the erosion of the traditional status of the white male, and more specifically, to the falling economic significance and power of the white male worker: "undone by offshored factory jobs, disappearing affordable housing, and unprecedented global movements of labour and capital, the age of the secure white male provider and nation-state sovereignty in the Global North is finished" ${ }^{57}$ Yet whilst the status of the white male patriarch has weakened, many of the social norms that correspond to that status remain in place, even though they have started to seem increasingly hollow. A connection could be drawn here to Nietzsche's dead God that would fit neatly with the ironic, self-deprecating dimensions of alt-right misogyny. On another, broader, level, however, this same idea also pertains to the ways in which neoliberal restructuring has dissolved the older reference points of class, community, and historical orientation. The "God" that has been vanquished in this sense is not the white patriarch, but rather the cohesion and functionality of collective subjectivity per se. Or, to put this in the terms of Pippin's interpretation of Hegel: the God that is missing - or has been occluded and undermined - is nothing less than the Absolute.

On a traditional, full-blown metaphysical reading of Hegel, the Absolute is the fundamental rational architecture and driving-force of all being (and 'being', in this sense, means nothing less than the totality of the cosmos). It is, in effect, a pantheistic 'God'. On Pippin's account, however, the Absolute has a much smaller remit. It is not the structure of being per se, but rather the conceptual structure through which Spirit constructs and conceives intelligible being. This means that Spirit's final knowledge of the Absolute is not the identification of a distinct entity or a fact. Instead, it is reason's full "understanding ... of its own activity" ${ }^{58}$ Such knowledge is not, therefore, "the

\footnotetext{
${ }^{55}$ Brown (2018), 70.

${ }^{56}$ Nietzsche (1996), 48.

${ }^{57}$ Brown (2018), 69.

${ }^{58}$ Pippin (1989), 70.
}

Araucaria. Revista Iberoamericana de Filosofía, Política, Humanidades y Relaciones Internacionales, año $21, \mathrm{n}^{\circ} 42$. Segundo semestre de 2019. Pp. 505-527. ISSN 1575-6823 e-ISSN 2340-2199 doi: 10.12795/araucaria.2019.i42.22 
achievement of some sort of first-order truth about what there is": instead, it is "our self-conscious justification of the possibility of any first-order truths about the world". ${ }^{59}$ It is not a final account of everything, but rather a full account of the structure of any possible account-giving. ${ }^{60}$ To know the Absolute, then, is to grasp the conceptual mechanics that underpin any instance of collective subjectivity (or rather Spirit), i.e. that articulate the shared norms through which the latter operates.

This means that there is no final arrest or Kojèveian "end of history" on this reading of Hegel. ${ }^{61}$ All we have here is the identification and comprehension of a structure that is, Pippin tells, us, in constant, open-ended, self-constitutive and self-determinate movement (it is a "self-consciousness about ...[the] process" of Spiritual life, Pippin writes, and not an acknowledgement of the latter's "final completion or termination"). ${ }^{62}$ In consequence, rather than a perspective on a completed past, we instead have a concern with construction of the future. ${ }^{63}$ Now, such a structure can never truly 'die', in the Nietzschean sense, as it must remain implicit in all forms of social and practical conceptuse. It can, however, be poorly actualised through flawed and irrational forms of social interaction. If that occurs, we end up with a situation in which the values, commitments, and normative practices of a social order fragment: they lose their coherence, and fail to afford meaningful self-determinacy for the actors involved. This echoes the Nietzschean idea of modernity's baseless, fragmented, and empty values, but it implies a rather different, albeit somewhat similar, response - not the affirmation of the will to power's creative potential, but rather the creation, through the norms of collective self-determinacy, of a shared future. ${ }^{64}$

59 Pippin (2007), 59-60.

${ }^{60}$ See Pippin (1989),247 and 257. Or, to put this in more Witgensteinian terms: the Absolute, on this reading, is something like the structure of all possible language-games; a structure, moreover, that can only be understood from within such games.

${ }^{61}$ The common conception of the notorious Hegelian 'end of history' stems from the work of Alexandre Kojève. During the 1930s, Kojève presented an enormously influential series of seminars on Hegel's Phenomenology of Spirit at the École Pratique des Hautes Études. These seminars were attended by some of the major figures in French twentieth century thought (e.g. Aron, Breton, Bataille, Lacan and Merleau-Ponty), and they greatly informed the Francophone reception of Hegel's ideas. In addition to fostering a focus on the Phenomenology, they advanced the idea that Hegel had, in effect, announced the end of history itself. The textual evidence for such a view is scant: Hegel refers to the "end of history" only once in his entire corpus. The phrase appears in a work that was composed, posthumously, from Hegel's lecture notes and from his students' own notes; and even there it only functions as part of a metaphor (Hegel (2004), 103). Remarks concerning the 'openness' of the future, or at least concerning the need for further historical work to be performed, can also be found elsewhere in his writings (see Stewart 1996 for useful commentary).

62 Pippin (1989), 247.

${ }^{63}$ This is central to the argument presented in (and thus the predicament described in) Pippin 2003.

${ }^{64}$ Mark Fisher's insightful comments on neoliberal society's inability to think the future are highly relevant here (see, for example, Fisher 2014) 
I have argued that the loss, or occlusion, of such a future is the pathology that underpins a great deal of modern demagogic politics. I shall close by looking at a particularly extreme illustration of this point: namely, the demagogic rhetoric of the new far-right, as advanced by some of the latter's prominent theorists. Their rhetoric can, I think, serve to illustrate the relevance of both Brown's emphasis on particularisation and the Hegelian loss of meaning and direction that I outlined earlier. This is because their particular version of demagogy is itself a flawed, symptomatic response to the problems identified by both Brown and Pippin. On the one hand, it reflects, and serves to channel, the anger and disillusionment bred by the particularisation that Brown describes. On the other, it offers palliative answers to such frustrations; answers that correctly identify a broader collapse of meaning and purpose, but which respond to that collapse by affirming the comforting but illusory sureties of tradition, nation, and biological identity, rather than by endorsing any kind of collective, universal orientation towards the future.

One of the peculiarities of the new Right is the degree to which it sometimes echoes, however inadvertently, the so-called 'identity politics' and criticisms of universalism that have been associated with the theoretical Left for the past several decades. This follows from its hostility to a globalised and purportedly multicultural (neo-)liberal order, and from its readiness to assert the authenticity of national and ethnic identity in opposition to such marketised cosmopolitanism. In France, for example, Alain de Benoist has claimed that the abstract universalism commonly associated with the European Enlightenment "is the basis of all totalitarianisms", and that such "homogenising universalism is only the projection and the mask of an ethnocentrism extended over the whole planet".65 likewise, in Russia, Aleksandr Dugin can be found claiming that the assertion of purportedly universal values is really "a form of ideological expression against a multiplicity of cultures". ${ }^{66}$ Against the abstract universality that they associate with those values, writers such as these affirm the importance of qualitative particularity and identity, albeit understood in terms of ethnos, nation and race. ${ }^{67} \mathrm{I}$ would argue that the rhetoric and appeal of demagogic theorists such as these accords with Brown's account of neoliberalism's degeneration of the social, and with her claims concerning the ways in which the privatisation of the social produces modes of subjectivity that are inclined to express unrest through the reactive assertion of particularity. This feeds, and is fed by, the demagogic presentation of reactive and confusedly particularistic

\footnotetext{
${ }^{65}$ de Benoist and Champetier, undated

${ }^{66}$ Dugin (2018), 193.

${ }^{67}$ Dugin, for example, understands "ethnos" as a "community of language, religion belief" and "daily life" (Dugin (2018), 47); similarly, Guillaume Faye has called for a revitalisation of "the values of the $\operatorname{arch} \underline{\boldsymbol{e}}$ ", and for "a folk community founded on the law of blood, culture and memory" (Faye (2010), 75).
} 
images of the meaning and orientation once afforded by the sociality that neoliberalism has steadily effaced. The nature of that particularisation fosters conservative retrospection (nation, tradition, heritage, etc.). Yet what is really missing, according to the perspective that I have tried to outline here, is an orientation towards the future. The difficult solution implied by Pippin's conception of social pathology, at least as I have employed it here, is to pursue such an orientation through the creation of structures and forms of interaction that differ from the empty universality of marketised equivalence, and that run counter to the antagonistic and essentialist particularity that characterises demagogic reactions to this malaise. Seen in these terms, then, modern demagogy can be understood as a symptom of a set of pathologically flawed social relations. 


\section{References:}

de Benoist, Alain, and Champetier, Charles (undated). 'Manifesto of the French New Right in Year 2000'. Available at https://pdfs.semanticscholar. org/5388/a0f125887a784acd36b2d2166705d42ae678.pdf

Brecher, Bob (2019). 'Universities: The Neoliberal Agenda', in Clack, Beverley, and Paule, Michele (eds.), Interrogating the Neoliberal Lifestyle. London: Palgrave Macmillan.

Brown, Wendy (2015). Undoing the Demos: Neoliberalism's Stealth Revolution. New York: Zone Books.

Brown, Wendy (2018). 'Neoliberalism's Frankenstein: Authoritarian Freedom in Twenty-First Century "Democracies"'. Critical Times, Vol.1, No.1.

Chitty, Andrew (2013). 'Recognition and Property in Hegel and the Early Marx'. Ethical Theory and Moral Practice, Vol.16, No.4.

Clark, John P. (2013). The Impossible Community: Realising Communitarian Anarchism. New York: Bloomsbury.

Dugin, Aleksandr (2018). The Fourth Political Theory. London: Arktos.

Faye, Guillaume (2010). Archeofuturism: European Visions of the PostCatastrophic Age. London: Arktos.

Fisher, Mark (2014). Ghosts of My Life: Writings on Depression, Hauntology and Lost Futures. Winchester: Zero Books.

Graeber, David (2013). 'On the Phenomenon of Bullshit Jobs: A Work Rant'. Strike!, \# 3.

Hegel, Georg Wilhelm Friedrich (1969). The Science of Logic. Translated by AV Miller. New York: Humanity Books.

Hegel, Georg Wilhelm Friedrich (1977). The Phenomenology of Spirit. Translated by AV Miller. Oxford: Oxford University Press.

Hegel, Georg Wilhelm Friedrich (2005). The Philosophy of Right. Translated by SW Dyde. New York: Dover Publications.

Houlgate, Stephen (2005). An Introduction to Hegel: Freedom, Truth and History. Oxford: Blackwell.

Inwood, Michael (2003). A Hegel Dictionary. Oxford: Blackwell.

Marx, Karl (1975). Early Writings. Translated by Rodney Livingstone and Gregor Benton. Middlesex: Penguin.

Marx, Karl (1990). Capital, Volume 1. Translated by Ben Fowkes. London: Penguin.

Mirowski, Philip (2013). Never Let a Serious Crisis Go to Waste: How Neoliberalism Survived the Financial Meltdown. London: Verso.

Nagle, Angela (2017). Kill all Normies: The Online Culture Wars from Tumblr and 4chan to Trump and the Alt-Right. Winchester: Zero Books. 
Nietzsche, Fredrich (1996). On the Genealogy of Morals. Oxford: Oxford University Press.

Nietzsche, Friedrich (2017). The Will to Power. London: Penguin.

Peterson, Jordan (2018). 12 Rules for Life: An Antidote to Chaos. Allen Lane: London.

Pippin, Robert (1989). Hegel's Idealism: The Satisfactions of SelfConsciousness. Cambridge: Cambridge University Press

Pippin, Robert (2003). Modernism as a Philosophical Problem: On the Dissatisfactions of European High Culture. Oxford: Blackwell Publishers Inc.

Pippin, Robert (2005). The Persistence of Subjectivity: On the Kantian Aftermath. Cambridge: Cambridge University Press.

Pippin, Robert (2007). 'You Can't Get There from Here: Transition Problems in Hegel's Phenomenology of Spirit'. Beiser, Frederick (ed.), The Cambridge Companion to Hegel, Cambridge: Cambridge University Press.

Pippin, Robert (2008). Hegel's Practical Philosophy: Rational Agency as Ethical Life. Cambridge: Cambridge University Press.

Pippin, Robert (2017). 'Hegel on Social Pathology: The Actuality of Unreason'. Crisis and Critique, Vol.4, No.1.

Stewart, Jon (ed.) (1996). The Hegel Myths and Legends. Illinois: Northwestern University Press.

Toscano, Alberto (2017). 'Notes on Late Fascism'. Available at http://www. historicalmaterialism.org/blog/notes-late-fascism 
